\title{
Praktický význam spirituality $v$ procese zvládania neobvyklých mentálnych symptómov
}

\author{
MATEJ PAULÍK*
}

Tento článok je primárne teoreticko-metodologickej povahy. Hlavným zámerom je načrtnút výskumný prístup, ktorým by som prispel k sociálne-vednému nahliadaniu na spiritualitu z hladiska jej praktických významov a funkcií v prostredí žitej každodennosti. Budem skúmat významy a funkcie, ktoré môže alternatívna spiritualita mat ako jeden z kultúrnych zdrojov využitel'ný pri vyrovnávaní sa s neobvyklými fyzickými a psychickými symptómami.

Spiritualita sa oddelila od svojich tradičných náboženských koreňov a začala sa objavovat ako významná téma $v$ mnohých akademických a profesionálnych disciplínach, mimo okruh tradičných náboženstiev. Snaha o jedinú definíciu sa tak môže javit značne problematicky. ${ }^{1} \mathrm{Z}$ rozličných definícií spirituality sa pre účely môjho výskumu javí ako najvhodnejšia tá, ktorú podáva Wouter Hanegraaff. Spiritualitu definuje ako akúkolvek ludskú prax, ktorá pomáha udržiavat kontakt medzi každodenným svetom a viac všeobecným meta-empirickým významovým rámcom cestou individuálnej manipulácie so symbolickými systémami. ${ }^{2}$ Takáto definícia spirituality je dostatočne široká na to, aby zastrešila koncepty a praktiky, ktorým sa budem $\mathrm{v}$ tomto texte venovat. Zároveň výstižne poukazuje na dôležitý aspekt týchto konceptov a praktík - na individuálnu manipuláciu so symbolickými systémami týkajúcimi sa meta-empirických významových rámcov. V princípe, píše Hanegraaff, je spiritualita bežným každodenným fenoménom. Každá osoba, ktorá obdaruje individuálnym nádychom

* Táto štúdia vznikla v rámci projektu „Výzkumné trendy v současné religionistice“ (MUNI/A/0858/2019), řešeného Ústavem religionistiky FF MU v roce 2020.

1 Peter R. Holmes, ,Spirituality: Some Disciplinary Perspectives“, in: Kieran Flanagan - Peter C. Jupp (eds.), A Sociology of Spirituality, Burlington: Ashgate Publishing 2007, 23-42: 24.

2 Wouter Hanegraaff, „New Age Religion and Secularization“, Numen 47/3, 2000, 288-312: 296. 
nejaké existujúce náboženské symboly, praktikuje svoju vlastnú spiritualitu. ${ }^{3}$ Spirituality môžu vyvstat na báze existujúceho náboženstva, ale rovnako dobre môžu vyvstat i bez neho. Typickým príkladom druhého zmieneného prípadu je podla Hanegraaffa New Age - komplex spiritualít vyvstávajúci na základoch pluralistickej sekulárnej spoločnosti. ${ }^{4}$ Fenomén, ktorý Hanegraaff vo svojom článku nazýva New Age, sa v sociálne-vedných prácach často označuje i ako alternatívna alebo holistická spiritualita. ${ }^{5}$ Pojmy ako New Age, holistická alebo alternatívna spiritualita chápem teda ako vzájomne zamenitelné. Práve tento typ spirituality bude v nasledujúcom texte predmetom môjho záujmu a budem ho pomenovávat ako alternatívnu spiritualitu.

Väčšina sociologických a religionistických textov venujúcich sa alternatívnej spiritualite vychádza najmä z kvantitatívnych foriem výskumu a zo štúdia pramennej literatúry rozličných náboženských či spirituálnych hnutí. Najväčší dôraz kladú na opis symbolických systémov charakterizujúcich alternatívnu spiritualitu, na opis jej typických organizačných foriem či na proces nahrádzania tradičnejších náboženských foriem alternatívnejšími spiritualitami. Medzi týchto autorov patria napríklad Paul Heelas a Linda Woodhead, ${ }^{6}$ Wouter Hanegraaf ${ }^{7}$ či David Voas a Steve Bruce. ${ }^{8}$ Väčšinou spiritualitu chápu len ako určitú špecifickú oblast̉ oddelenú od iných sfér či aspektov ludského života. To im neumožňuje povedat niečo viac o tom, ako ludia praktiky a koncepty alternatívnej spirituality používajú pri riešení svojich každodenných starostí.

K myšlienke skúmat praktické významy a funkcie spirituality pri organizovaní každodenného života $\mathrm{v}$ kontexte problematických a neistých životných situácií ma priviedol text Milana Fujdu „Od náboženstva k zvládaniu neistoty: Lekcia od tanečníkov“99 Autor v ňom navrhuje nahliadnut náboženstvo z perspektívy praktického zvládania neistoty, krehkosti a komplexnosti života. Takýto záujem podla Fujdu môže viest̉ k nasmerovaniu našej pozornosti $\mathrm{k}$ bežným usporiadavacím praktikám (ordinary

\section{Ibid., 300.}

4 Ibid.

5 Paul Heelas - Linda Woodhead et al., The Spiritual Revolution: Why Religion is Giving Way to Spirituality, Malden: Blackwell Publishing 2005, 7.

6 P. Heelas - L. Woodhead et al., The Spiritual Revolution...

7 W. Hanegraaff, ,New Age Religion and Secularization...“.

8 David Voas - Steve Bruce, ,The Spiritual Revolution: Another False Dawn for the Sacred", in: Kieran Flanagan - Peter C. Jupp (eds.), A Sociology of Spirituality, Burlington: Ashgate Publishing 2007, 43-61.

9 Milan Fujda, „From Religion to Ordering Uncertainty: A Lesson from Dancers“, in: Peik Ingman - Terhi Utriainen - Tuija Hovi - Mans Broo (eds.), The Relational Dynamics of Enchantment and Sacralization: Changing the Terms of the Religion Versus Secularity Debate, Bristol: Equinox Publishing 2016, 207-230. 
ordering practises) vo všeobecnom slova zmysle. V kontexte štúdia náboženstva nám takýto prístup umožňuje, aby sme náboženstvo prestali považovat za kategóriu analyticky oddelenú od ostatných ludských aktivít. ${ }^{10}$ Fujda d’alej tvrdí, že vd’aka ludskej tendencii kombinovat rozličné „,racionálne“ a „neracionálne“ stratégie prekonávania nepredvídatelných a krehkých situácií stráca teoretická predstava oddelených „,sekulárnych“ a „náboženských"sfér praktickú relevanciu. Klúčovým príkladom kombinovania rozličných „,racionálnych“ a „neracionálnych“ stratégií za účelom získania kontroly nad situáciou je podla Fujdu zvládanie chronických chorôb a bolestí so svojou požiadavkou na prechádzanie medzi medicínou založenou na dôkazoch, tradičnou vedou, mágiou, modlitbami a d'alšími praktikami. ${ }^{11}$

Ďalším dôležitým zdrojom pre metodologické rozvrhnutie môjho výskumu sú texty z oblasti transkultúrnej psychiatrie, ako i antropologické texty popisujúce chápanie neobvyklých psychických symptómov naprieč rozličnými historickými dobami a kultúrami. Z týchto potom najmä kniha Hlasy rozumu, hlasy šialenstva, ${ }^{12} \mathrm{v}$ ktorej Leudar s Thomasom popisujú rozličné spôsoby chápania fenoménu počutia hlasov v priebehu histórie, od antického Grécka až po súčasnost'. Dôležitým aspektom ich nahliadania na nezvyčajnú skúsenosṫ počutia hlasov je videnie tohto javu na pozadí spoločensko-kultúrnych podmienok danej doby. Skúmajú význam rozličných kultúrnych zdrojov pri definovaní a zvládaní symptómov, ktoré by západná psychiatria kategorizovala ako duševnú chorobu, v kontexte každodenného života. ${ }^{13}$ Inšpiratívnou prácou $\mathrm{z}$ tejto oblasti je i prípadová štúdia pojednávajúca o stavoch posadnutosti a západných psychiatrických kategóriách. ${ }^{14}$ Anglicko-brazílsky tím psychológov a psychiatrov v nej skúma vhodnost aplikácie diagnostickej kategórie disociatívnej poruchy osobnosti na stavy posadnutosti v podmienkach brazílskej kultúry, v rámci ktorej sú súčastou náboženského života umbandy. Tvrdia, že ak je pri takýchto neobyčajných skúsenostiach k dispozícii sociálna siet, v rámci ktorej sú interpretované ako zmysluplné a hodnotné, nemusia byt v princípe pre individualitu škodlivé. 15

10 Ibid., 209.

11 Ibid., 207.

12 Ivan Leudar - Philip Thomas, Voices of Reason, Voices of Insanity, London: Routledge - Philadelphia: Taylor and Francis 2000.

13 Ibid., 5.

14 Romara Delmonte - Giancarlo Luccheti - Alexander Moreira-Almeida - Miguel Farias, „Can the DSM-5 Differentiate between Nonpathological Possession and Dissociative Identity Disorder? A Case Study from an Afro-Brazilian Religion“, Journal of Trauma and Dissociation 17/3, 2016, 322-337.

15 Ibid., 332-333. 
Inšpiráciu čerpám taktiež z textov spadajúcich do oblasti antropológie medicíny. Buryho koncept biografickej disrupcie, popísaný v článku „Chronické choroby ako biografická disrupcia“"16 mi ukázal, že situáciu krízy vyplývajúcej z náročných zdravotných problémov je možné sledovat v určitých navzájom previazaných štádiách. Koncept určitej štruktúry priebehu biografickej disrupcie mi pomáha lepšie pochopit povahu situácií, v rámci ktorých môžu ludia siahnut po praktikách a konceptoch alternatívnej spirituality.

Moji komunikační partneri, s ktorými som sa v rámci svojho výskumu rozprával, zažívali neobvyklé psychické a fyzické symptómy, ktoré je možné v závislosti od okolností vyložit rozličnými spôsobmi a začlenit ich do rôznych usporiadaní praktickej práce s nimi. K chápaniu takto mnohoznačne definovatelných symptómov ako určitej hraničnej situácie ma priviedol najmä text Zdeňka Konopáska „V čom spočíva pravda náboženskej skutočnosti?"“17

Z viac všeobecného hladiska týkajúceho sa prístupu k empirickým dátam vychádzam z teoreticko-metodologických návrhov Bruna Latoura. Ten píše, že ked” sociálni vedci používajú pojem „sociálny“, predpokladajú tým stabilný stav vecí, určitý zväzok väzieb, ktorý následne možno použit na vysvetlenie ostatných fenoménov. Takéto chápanie stavu vecí je však podla Latoura chybné, pretože všeobecné pojmy typu „sociálno“ by sme nemali považovat za typ materiálu, aký máme na mysli napríklad pri pojmoch „,drevený“, „,biologický“, „železný“ či „mentálny“. Nejde teda o určitú špecifickú oblast̉ reality, oddelenú od oblastí iných, ${ }^{18}$ ale skôr o typ spojení medzi vecami, ktoré samy o sebe nie sú sociálne. ${ }^{19} \mathrm{~V}$ takomto prípade sa potom nesnažíme predpisovat svojim skúmaným objektom vopred daný poriadok či obmedzovat rozsah entít, ktoré môžu nejako pôsobit. Výskumník by sa mal snažit pozorne nasledovat samotných aktérov, pokúsit sa zachytit ich inovácie, i ked často divoké, aby sa tak naučil, čím sa sociálno - určitý kolektív zložený z rozličných heterogénnych prvkov - stalo v ich rukách. ${ }^{20}$ Podobným spôsobom, akým Latour pracuje s pojmom sociálna, by som rád narábal i s pojmom spirituality. Namiesto predpokladu samostatne existujúcej sféry alternatívnej spirituality, oddelenej od iných sfér ludskej činnosti, budem analyzovat prepojenia medzi prakti-

16 Michael Bury, „Chronic Illness as Biographical Disruption“, Sociology of Health and Illness 4/2, 1982, 167-182.

17 Zdeněk Konopásek, „V čem spočívá pravda náboženské skutečnosti? Sociologický pohled na mariánská zjevení a démonické posedlosti“, Biograf 52-53, 2010, 89-101.

18 Bruno Latour, Reassembling the Social: An Introduction to Actor-Network Theory, Oxford: Oxford University Press 2005, 1.

19 Ibid., 5.

20 Ibid., 11-12. 
kami a konceptmi alternatívnej spirituality a bežnými každodennými starostami ludských životov. Takýto prístup mi umožní nahliadnut rozličné prepojenia medzi praktikami a konceptmi alternatívnej spirituality a aktivitami, ktoré do tejto kategórie nespadajú.

\section{Výskumné prostredie}

Empirické dáta pre svoj výskum som získaval a nad’alej získavam prostredníctvom biografických rozhovorov. Základným kritériom pre výber komunikačných partnerov a ich začlenenie do výskumu je skúsenost' s neobvyklými psychickými a fyzickými symptómami, a zároveň ich snaha zvládnut túto skúsenosti okrem iného i prostredníctvom konceptu psychospirituálnej krízy. Do tejto chvíle som uskutočnil devät biografických rozhovorov. Prvé kontakty na komunikačných partnerov som získal s pomocou psychoterapeutickej organizácie Diabasis. ${ }^{21}$ Ďalšie kontakty som získal prostredníctvom pátrania na rozličných internetových stránkach a fórach, venujúcich sa skúsenostiam s psychospirituálnou krízou. Niektorých komunikačných partnerov som objavil vd’aka cenným doporučeniam na možných záujemcov, ktoré som dostal v rámci predošlých výskumných rozhovorov (tzv. metóda snehovej gule).

Spoločné kritériá výberu komunikačných partnerov nie sú prekážkou pestrosti ich vztahov k rozličným stratégiám vyrovnávania sa s problematickou životnou situáciou. Ich postoje voči rozličným terapeutickým inštitúciám, prostredníctvom ktorých sa snažili svoju neobvyklú skúsenost̉ zvládnut či sa $v$ nej aspoň lepšie zorientovat', sa taktiež značne líšia. Niektorí z nich navštevujú alebo navštevovali psychiatra, či boli hospitalizovaní v psychiatrickej liečebni. V rozprávaniach iných vystupuje psychiatria len ako hypotetická možnost'. Mnohokrát len ako stereotypizovaná predstava, voči ktorej sa kriticky vymedzujú a svoju alternatívnu terapiu voči nej stavajú v určitých aspektoch do protikladu. Väčšina mojich komunikačných partnerov prišla $\mathrm{v}$ nejakej forme do kontaktu $\mathrm{s}$ organizáciou Diabasis, ktorá s klientmi psychoterapeuticky pracuje s pomocou využitia konceptov psychospirituálnej krízy. Intenzita spolupráce s Diabasis bola u mojich komunikačných partnerov rôznorodá. Niektorým z nich bola alternatívna psychoterapia komplementárnou pomocou k liečbe psychiatrickej. Pre iných predstavovala voči klasickej psychiatrii a farmakologickej

21 Vid' internetové stránky organizácie <http://www.diabasis.cz/>. Diabasis je psychoterapeutická organizácia, ktorá pomáha lud’om prechádzajúcim psychospirituálnou krízou. Oproti klasickej psychiatrii sa líši svojím pohladom na neobvyklé symptómy. Po splnení určitých diagnostických kritérií sa ich nesnaží psychofarmaceuticky potlačit, no skôr ich za účelom liečby v bezpečnom prostredí zosilnit a pomôct klientovi pochopit ich príčinu. 
liečbe alternatívu. Niektorí moji komunikační partneri spolupracovali s Diabasis len krátkodobo, prostredníctvom malého počtu konzultačných stretnutí. Iným sa stala psychoterapia v tejto organizácii dlhodobou záležitostou. Okrem psychiatrických a psychoterapeutických inštitúcií hladalo mnoho $\mathrm{z}$ nich pomoc i v d'alších rozličných podobách alternatívnej medicíny či $\mathrm{v}$ seminároch a prednáškach zameraných na alternatívnu spiritualitu. ${ }^{22}$

Biografické rozhovory s komunikačnými partnermi som uskutočňoval u nich doma, v nimi vybranej reštaurácii alebo čajovni. Na začiatku som poprosil o volné rozprávanie o ich skúsenostiach s neobvyklými psychickými a fyzickými symptómami, o okolnostiach ich vzniku, o ich priebehu, o spôsobovaných tažkostiach a podobách vyrovnávania sa s nimi. Volné rozprávanie som následne rozvíjal doplňujúcimi otázkami. Rozhovory som viedol v duchu tradície chápajúceho rozhovoru, ako ho načrtáva francúzsky sociológ Jean-Claude Kaufmann. ${ }^{23}$ Do rozprávaní som, ak to bolo situačne vhodné, aktívne vstupoval, vyjadroval vlastné myšlienky a snažil sa tým vytvorit uvol’nenejšiu atmosféru, a zároveň podporit rozvinutie preberaných tém. Musel som však, ako píše Kaufmann, neustále dávat pozor, aby som sa napriek konverzačnému štýlu nenechal do rozhovoru úplne vtiahnut a neprestával v pamäti držat témy a otázky, na ktoré som sa zameriaval. ${ }^{24}$ Týmto spôsobom som následne mohol rozprávania na dotyčných miestach viesṫ $\mathrm{k}$ d’alšiemu rozvinutiu prostredníctvom položenej otázky či komentára.

Neobvyklými symptómami prežívanými mojimi komunikačnými partnermi mám na mysli javy, akými sú napríklad počutie hlasov, zrakové vízie, zvláštne telesné pocity, vôlou nekontrolované pohyby tela, zmeny v zmyslovom vnímaní či stratu motivácie pokračovat v zabehnutých spôsoboch života. Väčšinou ide o symptómy, ktoré klasická psychiatria nahliada ako halucinácie a bludy. Napríklad počutie hlasov považuje väčšina psychiatrov za symptóm, ktorý by mal byt potlačený, podobne ako kašel' či bolesti. ${ }^{25}$ Bežne prijímanou stratégiou v psychiatrii je snaha vyhnút sa diskusii s pacientom o jeho abnormálnych skúsenostiach. Halucinácie a psychotické symptómy nemajú v takomto pojatí samy o sebe hodnotu. Predstavujú len nevyhnutný dôsledok narušeného fungovania mozgu, ktorý je primárne zodpovedný za vzniknutú chorobu. ${ }^{26}$ Nájdu sa ale i psy-

22 Napríklad prednášky a semináre Dana Millmana, akcie juhoamerických šamanov, akupunktúra, semináre zamerané na prácu s dychom vychádzajúce z budhistických tradícií.

23 Jean-Claude Kaufmann, Chápající rozhovor, Praha: SLON 2010.

24 Ibid., 57.

25 I. Leudar - P. Thomas, Voices of Reason..., 51.

26 Ibid.,111. 
chiatri, ako napríklad Christina a Stanislav Grofovi, tvrdiaci, že mnohé prípady neobvyklých stavov vedomia, dokonca i značne dramatických a dosahujúcich takmer psychotických rozmerov, nemusia nutne predstavovat symptómy choroby v lekárskom zmysle. Nahliadajú na ne skôr ako na náročné štádiá vývoja vedomia - psychospirituálne krízy. ${ }^{27}$ Je podla nich vel'mi dôležité tento stav rozpoznat a pristupovat k nemu obozretne, s ohladom na jeho pozoruhodný pozitívny potenciál pre osobný rast a vyliečenie, obvykle nerozlíšený rutinnou farmakologickou liečbou. ${ }^{28}$

Vo svojom výskume sa budem zameriavat na náročné ludské vol'by a balansovanie medzi rozličnými možnostami výkladu a stratégiami narábania s týmito symptómami. Z tohto dôvodu používam v rámci možností čo najviac neutrálny jazyk, snažiac sa touto cestou vopred neuprednostňovat biomedicínske, no ani alternatívne formy interpretácií. Nie je v mojom bádatel'skom záujme a kompetenciách rozhodovat o nejakej predpokladanej skutočnej povahe týchto javov. O povahe daných symptómov sa s velkou opatrnostou vyjadrujú dokonca i niektorí odborníci na problematiku duševného zdravia. Michael Vančura, psychológ a psychoterapeut z Diabasis, napríklad rozpráva o tom, že na odborných seminároch trávia s kolegami mnoho času diskusiami nad možnostami rozlíšenia psychospirituálnej krízy s prvkami psychózy od psychózy s prvkami psychospirituálnej krízy. ${ }^{29}$ Namiesto určenia skutočnej povahy skúmaného javu ma budú zaujímat skôr definície, výklady a praktiky, odohrávajúce sa v interakcii medzi mojimi komunikačnými partnermi a najrozličnejšími spoločenstvami, inštitúciami, lud’mi a predmetmi, prostredníctvom ktorých sa objektivita daných situácií ustanovuje a prostredníctvom ktorých sa trpiaci ludia snažia svoju situáciu čo najlepšie zvládnut.

\section{Súčasný stav bádania}

Jednou z motivácii k skúmaniu praktických významov spirituality mi je určitá jednostrannost perspektív, z ktorých sa na túto problematiku nahliada $\mathrm{v}$ akademických disciplínach religionistiky a sociológie náboženstva. Jednostrannostou myslím najmä orientáciu jednak na vel'ké sociologické otázky spojené so sekularizačnou debatou, jednak na premenu rozličných podôb religiozít a spiritualít $\mathrm{v}$ čase a premenu ich úlohy $\mathrm{v}$ spoločnosti. $\mathrm{V}$ posledných rokoch môžeme narazit i na štúdie zameriavajúce sa na

27 Christina Grofová - Stanislav Grof, Krize duchovního vývoje: Když se osobní transformace promění v krizi, Praha: Chvojkovo nakladatelství 1999, 18.

28 Ibid., 19.

29 Michael Vančura, „Rozhovor na ALLfestivalové téma zdraví, léčení a terapie“ [video, online], <https://www.youtube.com/watch?v=OKQSF8_0yOI>, 2. 5. 2017 [16. 1. 2019]. 
význam rozličných podôb alternatívnej spirituality vo vztahu k „malým“ každodenným problémom jednotlivcov. Práve do tohto prúdu bádania by som sa chcel svojím výskumom zaradit.

$\mathrm{O}$ alternatívnej spiritualite dnes píše mnoho bádatelov. Voas, Bruce, ${ }^{30}$ Heelas $^{31}$ a Woodhead ${ }^{32}$ sa zaoberajú vztahmi a rozdielmi medzi týmito formami spirituality a tradičnejšími náboženstvami. Túto problematiku väčšinou spracovávajú formou popisu rozličných systémov vier spirituálneho a holistického milieu. $\mathrm{Z}$ ich práce získavame najmä poučenie o konceptuálnej výstavbe daných spirituálnych symbolických svetov. Poskytujú nám prehlad klúčových predstáv daných symbolických systémov, ako i lepšiu orientáciu v rozdieloch medzi alternatívnymi spiritualitami a tradičnejšími náboženstvami. Taktiež sa zaujímajú o spôsoby, ktorými sa ludia zúčastňujúci sa aktivít alternatívnych spiritualít organizujú, či prostredníctvom ktorých medzi sebou komunikujú. Ďalší bádatelia, ako napríklad Wouter Hanegraaff ${ }^{33}$ alebo Hugh B. Urban, ${ }^{34}$ sledujú historické korene alternatívnej spirituality a rozličných jej prúdov a spôsoby ich interpretačnej práce s rozličnými náboženskými, ako i sekulárnymi symbolickými systémami. Ďalšie štúdie sa zaoberajú vplyvom alternatívnej spirituality na uzatváranie sa ludí do prílišného individualizmu či naopak, na zapájanie sa do rozličných kolektívnych dobrovolníckych a sociálne-politických aktivít. Medzi autorov premýšlajúcich nad alternatívnou spiritualitou v zmysle jej vplyvu na sociálnu angažovanosṫ či naopak prílišný individualizmus patria napríklad Oh a Sarkisian ${ }^{35}$ alebo Berghuijs, Bakker a Pieper. ${ }^{36} \mathrm{O}$ tom, že alternatívna spiritualita by mohla prispievat $\mathrm{k}$ atomizácii medziludských vzṫahov a zbavovaniu sa spoločenskej zodpovednosti, píšu napríklad Carrette a King. ${ }^{37}$ Význam premýšlania o spiritualite ako o novo vyvstávajúcej kultúrnej kategórii, ktorá má potenciál narušit zabe-

30 D. Voas - S. Bruce, ,The Spiritual Revolution...“.

31 Paul Heelas, „The Holistic Milieu and Spirituality: Reflections on Voas and Bruce“, in: Kieran Flanagan - Peter C. Jupp (eds.), A Sociology of Spirituality, Burlington: Ashgate Publishing 2007, 63-80.

32 P. Heelas - L. Woodhead et al., The Spiritual Revolution...

33 W. Hanegraaff, ,New Age Religion and Secularization...“.

34 Hugh B. Urban, New Age, Neopagan, and New Religious Movements: Alternative Spirituality in Contemporary America, Berkeley: University of California Press 2015.

35 Seil Oh - Natalia Sarkisian, ,Spiritual Individualism or Engaged Spirituality? Social Implications of Holistic Spirituality among Mind-Body-Spirit Practitioners", Sociology of Religion 73/3, 2012, 299-322.

36 Joantine Berghuijs - Cok Bakker - Jos Pieper, „New Spirituality and Social Engagement“, Journal for the Scientific Study of Religion 52/4, 2013, 775-792.

37 Jeremy Carrette - Richard King, Selling Spirituality: The Silent Takeover of Religion, London: Routledge 2004. 
hnuté spôsoby sociálne-vedného uvažovania o spoločnosti v dichotomických kategóriách sekulárne/náboženské, vyzdvihujú Huss ${ }^{38}$ a Königstedt. ${ }^{39}$

Ak sa títo bádatelia zameriavajú napríklad i na pochopenie možných praktických funkcií, ktoré spiritualita v každodenných životoch bežných ludí môže zohrávat, činia tak len sporadicky a pomerne povrchným spôsobom. Predpokladám, že príčinou tohto javu sú jednak otázky, ktoré si dané štúdie kladú, jednak povaha dát, z ktorých čerpajú.

Tie sú tvorené najmä dvoma typmi zdrojov. Jedným sú náboženské pramenné texty, druhým informácie získané z dotazníkov. Paul Heelas, používajúci v určitom období svojho akademického písania o alternatívnej spiritualite pre jej pomenovanie pojem New Age, tvrdí, že ludia sa New Age aktivitám venujú $\mathrm{z}$ dôvodu pocitovania pozitívnych zmien v ich životoch, prinášaných týmito praktikami. Snažia sa prostredníctvom nich vyriešit problémy identity, ktorých príčiny majú korene v konvenčných súčasných formách života. ${ }^{40}$ Pre mnohých ludí je tak príklon k New Age snahou vyrovnat sa s vážnymi problémami, prejavujúcimi sa nepríjemným emočným a fyzickým rozpoložením. ${ }^{41}$ Heelasove poznatky sú zaujímavé a hlbšieho porozumenia hodné. Vzhladom na snahu dané výroky lepšie pochopit je však podla mňa problematickým zdôvodňovat tieto závery prevažne poznatkami z kvantitatívne organizovaných výskumov, spočívajúcich vo vypíňaní dotazníkov. Konštatovanie o priaznivom efekte New Age praktík na riešenie ludských životných problémov je podložené tvrdením $82 \%$ participantov o tom, že sa stali „viac spirituálnymi“, $80 \%$ participantov d’alej tvrdí, že ich život sa stal „,viac zmysluplným“, 72 \% respondentov sa stalo „viac štastnými““, $71 \%$ zas ,viac naplnenými““ atdd. ${ }^{42}$ Nespochybňujem možnú pravdivosṫ týchto záverov. Nedostatočnou sa mi javí ich malá výpovedná hodnota vzhladom na otázku, aké konkrétne procesy vedú daných ludí k pozitívnemu hodnoteniu spirituálnych praktík. Na základe prehlásení o stávaní sa viac spirituálnym, štastným a naplneným je tažké si niečo konkrétnejšie predstavit. Nedozvedáme sa z nich, čo to znamená byt

38 Boaz Huss, ,Spirituality: The Emergence of a New Cultural Category and Its Challenge to the Religious and the Secular", Journal of Contemporary Religion 29/1, 2014, 47-60.

39 Christiane Königstedt, „Religio-Spiritual Strategies of Self-help and Empowerment in Everyday Life: Selected Cases of Spirituality in Germany“, in: Tore Ahlbäck - Björn Dahla (eds.), Post-Secular Religious Practices, Turku: The Donner Institute for Research in Religious and Cultural History 2012, 178-200.

40 Paul Heelas, The New Age Movement: The Celebration of the Self and the Sacralization of Modernity, Oxford: Blackwell Publishers 1996, 174.

41 Ibid., 203.

42 Ibid., 182. Participanti výskumu boli čitatelia britského magazínu o duchovnom rozvoji Kindred Spirit. Na dotazník ich odpovedalo 900. 
spirituálny, v akej situácii to môže byt dôležité, alebo čo tým môžeme v konkrétnom kontexte získat.

V úvode tohto článku píšem, že by som rád prispel k sociálne-vednému pochopeniu praktík a konceptov alternatívnej spirituality $\mathrm{v}$ kontexte ich významov a funkcií v každodennom živote ludí. V úvode tejto časti zas píšem, že k takémuto poňatiu skúmania spirituality ma viedla určitá jednostrannost perspektív, z ktorých sa na túto problematiku nahliada $\mathrm{v}$ akademických disciplínach religionistiky a sociológie náboženstva. Je však pravdou, že $\mathrm{v}$ posledných rokoch sa objavujú i kvalitatívne zamerané štúdie pojednávajúce spiritualitu v jej rozličných praktických významoch pre životy jednotlivcov. Laurel Zwissler sa v knihe Náboženstvo, feminizmus, aktivizmus: Kozmológia prepojenia zameriava i na praktický význam alternatívnej spirituality pre jej komunikačné partnerky. ${ }^{43}$ Prichádza na to, že rozprávania o spiritualite mnohokrát slúžia ako stratégia účelového dištancovania sa od sekulárne, ako i od nábožensky konštruovanej politiky. ${ }^{44}$ Sociálne aktivistky, zúčastňujúce sa života nejakej náboženskej komunity, tak môžu siahnut po populárnom rozdelení medzi spiritualitou a náboženstvom, aby ostatným aktivistom dali najavo, že netrpia falošným utlačovatel'ským náboženským vedomím, voči ktorému sa sekulárne orientovaní aktivisti mnohokrát vymedzujú. ${ }^{45}$ Zároveň sa však skrze identifikáciu so spiritualitou, chápanou v zmysle všeludskej a kultúru prekračujúcej vnútornej skúsenosti, mohli dobre dorozumiet' s aktivistami inej náboženskej príslušnosti. ${ }^{46}$ Spirituálny diskurz im tak poskytuje praktický nástroj umožňujúci postavit sa do strednej pozície medzi náboženskými inštitúciami a sekulárnymi aktivistickými komunitami. ${ }^{47}$

Ďalšími kvalitatívne zameranými prácami z oblasti sociológie náboženstva, pre mňa inšpiratívnymi svojím prístupom ku skúmaniu spirituality, sú texty „Hladanie istoty: Za hranicou ájurvédy ako alternatívnej medicíny“ od Alžběty Wolfovej ${ }^{48}$ a „Posilnenie a artikulácia schopnosti jednat medzi fínskymi praktikantmi jogy“ od Månsa Broo a Christiane Königstedt. ${ }^{49}$ Wolfová píše, že v centre záujmu väčšiny štúdií o ájurvéde stoja interpretácie premien ájurvédskej náuky a praxe, kedy sú jej západné

43 Laurel Zwissler, Religious, Feminist, Activist: Cosmologies of Interconnection, Lincoln: University of Nebraska Press 2018.

44 Ibid., 149.

45 Ibid., 157.

46 Ibid., 149.

47 Ibid., 155.

48 Alžběta Wolfová, „Hledání jistoty: Za hranicí ájurvédy jako alternativní medicíny“, Biograf 63-64, 2016, 45-70.

49 Måns Broo - Christiane Königstedt, „Empowerment and the Articulation of Agency among Finish Yoga Practitioners“, in: Peik Ingman - Terhi Utriainen - Tuija Hovi Måns Broo (eds.), The Relational Dynamics of Enchantment and Sacralization: 
formy stavané do kontrastu k tradičnej či súčasnej indickej podobe ájurvédy. Minimum bádatelov sa však zameriava na skúsenosṫ ludí, ktorí ájurvédu praktikujú. ${ }^{50} \mathrm{Ak}$ už aj hovoria o význame ájurvédy pre jednotlivca, poukazujú na jej zosúladenie s ich osobnou filozofiou, na stratégie získavania ich dôvery či na jej vplyv na premenu porozumenia sebe a svojmu okoliu. Čo týmto štúdiám podla Wolfovej chýba, je interpretácia toho, aké konkrétne neporozumenie, aké konkrétne dilemy a vlastné neistoty ludia prostredníctvom adoptovania ájurvédského svetonázoru, ako i praktikovaním ájurvédy riešia. Tieto štúdie d’alej podla Wolfovej hovoria o nespokojnosti ludí s odosobnenou zdravotnou starostlivostou, detradicionalizáciou súčasnej spoločnosti, nezaoberajú sa však už tým, na základe akých skúseností vzniká nespokojnosti ludí, ktorú následne pomocou ájurvédy riešia. ${ }^{51}$ Broo a Königstedt v kontexte každodenného diania empiricky skúmajú vztahy jogovej praxe a situačne podmieneného rozvažovania medzi posilňovaním jedincovej schopnosti jednat a prenášaním zodpovednosti za rozličné životné udalosti na externé objekty a vplyvy. ${ }^{52}$

$\mathrm{V}$ snahe prispiet k sociálne-vednému porozumeniu alternatívnej spiritualite, $\mathrm{v}$ zmysle jej pragmatického využívania pri riešení konkrétnych ludských problémov v konkrétnych situáciách po vzore vyššie načrtnutých textov, som siahol po d’alších teoreticko-metodologických zdrojoch majúcich pôvod najmä $\mathrm{v}$ etnograficky zameranej antropológii medicíny a v transkultúrne orientovaných antropologicko-psychiatrických štúdiách.

\section{Neobvyklé symptómy v rozličných výkladových kontextoch}

Inšpiratívny náhlad na možnosti skúmania praktických významov spirituality pri riešení životných problémov som čerpal z humanitne zameraných disciplín venujúcich sa problematike narušenia ludského zdravia (fyzického alebo mentálneho), utrpenia a umierania. Napríklad pre ludí pracujúcich v hospicoch sa spirituálne otázky stávajú záležitostou každodennej komunikácie s lud’mi, ktorým v poslednej fáze života pomáhajú zmierit sa so smrtou. ${ }^{53}$ Pri kontakte s ontologicky ohrozujúcimi skúsenostami tematika transcendencie sveta v podobe Boha, určitý daný životný rád a predstava vztahov pretrvávajúcich po smrti človeka fungujú v rámci

Changing the Terms of the Religion Versus Secularity Debate, Bristol: Equinox Publishing 2016, 65-84.

50 A. Wolfová, Hledání jistoty..., 47.

51 Ibid., 48-49.

52 M. Broo - Ch. Königstedt, „Empowerment and the Articulation of Agency...“.

53 Petra Závorková - Roman Vido, „Když jí otřu obličej, tak je to modlitba“ [online], Biograf 52-53, 2010, <http://www.biograf.org/clanky/clanek.php?clanek=v5301>, 6. 7. 2011 [10. 1. 2018], 120 odst.: odst. 2. 
zmiernenia existenčne ohrozujúcich pocitov ako zastrešujúci baldachýn schopný danú situáciu preklenút a zmiernit jej dopad. ${ }^{54}$

Larsen popisuje rozmanitost' kultúrnych zdrojov, ktoré je možné mobilizovat v procese vyrovnávania sa s prvým zážitkom psychózy. ${ }^{55}$ Tradičné učenie klasickej psychiatrie o „chorobe a pacientoch“ neboli pre daných ludí jediným zdrojom umožňujúcim orientáciu $\mathrm{v}$ neobvyklej situácii. Medzi využívané interpretačné rámce patrili i koncepty alternatívne voči klasickému psychiatrickému výkladu, pochádzajúce z rozličných náboženských učení a hlbinne psychologických teórií. Odlišné chápanie príčin psychóz viedlo i $\mathrm{k}$ odlišnému spôsobu práce $\mathrm{s}$ danými symptómami. ${ }^{56}$ Príkladom podobného prístupu je i v úvodnej kapitole spomínaná prípadová štúdia anglicko-brazílskeho tímu psychológov. Skúmali vhodnost̉ aplikácie psychiatrickej kategórie disociatívnej poruchy osobnosti v kultúrnom prostredí, v ktorom sú takéto symptómy miestnym náboženským systémom interpretované ako stavy posadnutosti. ${ }^{57}$ Stavy posadnutosti z tohto náboženského pohladu nie sú stigmou. Naopak, môžu byt predzvestou životnej dráhy v roli šamana. Autori viedli sériu naratívnych rozhovorov so staršou liečitel'kou brazílskej umbandy. Umbanda je brazílske náboženstvo zahŕňajúce $\mathrm{v}$ sebe elementy $\mathrm{z}$ juhoamerických, afrických a rímsko-katolíckych tradícií a jedným z jeho klúčových elementov sú práve stavy posadnutosti duchmi. ${ }^{58} \mathrm{~V}$ dobe uskutočňovania prípadovej štúdie už dospelá a uznávaná liečitel'ka zažívala od detstva nevšedné stavy. Akoby sa jej niekto vkrádal do mysle a našeptával rozličné myšlienky. Vyrastala $\mathrm{v}$ rodine s rímsko-katolíckym vyznaním, pre ktorú boli takéto zážitky neprijatelné. Rodičia jej o nich zakazovali rozprávat a ona sa cítila previnilo. Rodinné zákazy však nemali vplyv na výskyt našepkávaní a budúca liečitel'ka mala potrebu o nich rozprávat. ${ }^{59}$ Situácia sa stupňovala. Jej tela sa zmocňovala nepoznaná neznáma sila. Nevšedné zážitky neboli nepríjemné. Občas sa bála ich nezvyčajnosti, nedostatku kontroly nad nimi a absencie vedomostí o nich, no zároveň jej spôsobovali potešenie a prinášali mier. ${ }^{60}$ Najväčší strach však pocitovala z možnosti označenia za duševne chorú. Vylúčenie zo spoločenského života by v prípade naplnenia takéhoto scenára bolo pravdepodobné. Diagnostikovanie duševnej

54 Ibid., odst. 118.

55 John Aggergaard Larsen, „Finding Meaning in First Episode Psychosis: Experience, Agency, and the Cultural Repertoire“, Medical Anthropology Quarterly 18/4, 2004, 447-471.

56 Ibid.

57 R. Delmonte - G. Lucchetti et al., „Can the DSM-5 Differentiate between Nonpathological Possession...", 324.

58 Ibid., 323.

59 Ibid., 327.

60 Ibid., 330-331. 
choroby by jej, ako povedala, zabránilo v nájdení duchovného domova. Nestala by sa tým, kým je. ${ }^{61}$ Autori na základe analýz predpokladajú, že diagnostikovanie disociatívnej poruchy osobnosti by u dotyčnej informátorky pravdepodobne viedlo k silnému sociálnemu konfliktu a kultúrnej neakceptovatelnosti jej skúseností. Z toho d’alej odvodzujú myšlienku, že ak sú disociatívne skúsenosti zasadené do vhodného kognitívneho rámca, systému vier a sociálnej siete, kde sú akceptované ako pozitívne a zmysluplné, nemusia byt pre individualitu zo zásady škodlivé. Tieto skúsenosti však môžu byt stresujúce a poškodzujúce, ak jedincovi nie je k dispozícii podporujúca sociálna siet a vhodný kognitívny rámec. ${ }^{62}$

Iným príkladom dôležitosti vhodného kognitívneho rámca a podpornej sociálnej siete pre úspešné zvládnutie podobných neobvyklých skúseností je i prípad môjho komunikačného partnera Martina. ${ }^{63}$ Počas púte, na ktorú sa vydal v spoločnosti priatelov, sa jeho telo a mysel dostali do víru podivuhodných úkazov. Prežíval príbehy zo života Ježiša Krista a Jána Krstitela. Kráčajúc po ceste a v zmysle Ježišovho kríža nesúc drevené poleno na ramene, si oproti idúce auto a stádo kráv vykladal ako obdobu Ježišových pokušení. Ked' sa na oblohe vyformoval mrežovitý vzor, postrehol Martin, že niečo nie je úplne v poriadku. Na druhý deň mu telom pretekali obrovské prívaly energie, a tak sa prichytil trávy, aby neodletel. Po troch dňoch podobne neobvyklých zážitkov sa postupne navrátil k bežnejšiemu vnímaniu a oznámil kamarátovi, že sa asi zbláznil. Spätne, počas rozvíjania spomienok v rámci nášho rozhovoru, považoval Martin za vel'ké štastie, že sa tieto udalosti odohrali počas púte. Retrospektívne ju vnímal ako bezpečné prostredie. Bezpečné $\mathrm{v}$ tom zmysle, že sa v danom priestore nevyskytoval nikto, kto by sa ho pokúsil zaviest̉ na psychiatrickú kliniku. Namiesto paniky a zmätku prejavili spolupútnici voči nevšedným zážitkom pochopenie. Celá pút tak podla Martinových slov získala omnoho vážnejší nádych a turistika sa premenila na skutočnú náboženskú pút:

Ono to zasáhlo celou tu skupinu. Že jsme v tom nějak víceméně byli ponořeni všichni. Nebylo to tak, že by to bylo jenom u mě. ... Ale současně to tu skupinu neuvěřitelně stmelilo a nás to všechny přivedlo velmi intenzivně na to, že jsme na pouti, a ne na zájezdu. ${ }^{64}$

Jeho spolupútnik, absolvent jungiánskeho terapeutického výcviku, bol otvorený možnosti interpretovat neobvyklú skúsenosṫ ako psychospirituálnu krízu. Mohlo však íst i o vážnejší problém. Nebol si výkladom istý.

61 Ibid., 333.

62 Ibid., 332-333.

63 Všetky mená komunikačných partnerov uvedené v tomto texte sú za účelom ochrany ich súkromia pozmenené.

64 Rozhovor z dňa 8. 1. 2019. 
Odbornejšie posúdenie prenechal kompetentnejšej osobe a dal Martinovi kontakt na terapeuta z organizácie Diabasis. Po dvojhodinovom rozhovore s terapeutom bol Martin uistený, že s najväčšou pravdepodobnostou išlo o psychospirituálnu krízu. Prestal tým pádom svojim skúsenostiam z púte pripisovat negatívne atribúty bežne spájané s duševnými poruchami a do vel'kej miery sa zbavil strachu $\mathrm{z}$ ich prepuknutia. Uistenie o nepatologickom charaktere trojdňovej nezvyčajnej skúsenosti Martin vnímal ako vel'mi významnú pomoc. Neistá povaha zážitku nabrala prostredníctvom slov psychoterapeuta konkrétnejšie kontúry:

Terapeut řekl: Byla to psychospirituální krize. To byla pro mě zásadní pomoc. Kdyby mi to neřek, kdybych se dostal někam jinam, tak bych možná zkoumal, co to se mnou bylo. Bylo to zdravý? Nebylo to zdravý? Tím to pro mě vlastně jako osvobodil od toho, abych se to nějak snažil někam dál zaškatulkovávat. A tím vlastně pro mě byla ta největší služba. Je to psychospirituální krize, velmi pravděpodobně už se to nebude opakovat. To bylo pro mě to, co mi opravdu pomohlo. Že jsem nebloudil někde a prrijal jsem to tak, jak to je, a přestal jsem to tak nějak jako démonizovat. Přestal jsem se toho bát. Protože to, co bych si z toho jinak odnes, by byl asi strach, jestli se mi to zas nestane znova, nebo něco takovýho. A to díky tomuhle tomu nebylo. ${ }^{6}$

Môžeme si tak všimnút viacero faktorov majúcich významný dopad na Martinovu skúsenost́. Prostredie, v ktorom neobvyklé stavy zažíval, bolo tematicky spriaznené s ich obsahom. Možno sa na formovaní ich obsahu i podielalo. Na svojej púti bol Martin obklopený lud'mi otvorenými možnosti zažívat náboženské vízie, a tým pádom ochotnými vzdat sa pokušenia automaticky ich interpretovat ako patológiu. I to ich zdržalo od snahy pút ukončit a privolat lekársku pomoc. Je však pravdou, že zároveň nedisponovali praktickými prostriedkami potrebnými k zaisteniu akútnej lekárskej pomoci. Najbližšia cesta vhodná pre automobilovú dopravu bola velmi vzdialená. Nemenej dôležitým faktorom vedúcim $\mathrm{k}$ popisovanému vývoju situácie bol i Martinov kamarát s jungiánskym terapeutickým výcvikom, o ktorého rady sa mohol opriet. Ten mu napokon i sprostredkoval kontakt na psychoterapeuta pracujúceho $\mathrm{s}$ konceptom psychospirituálnej krízy. Terapeut s povestou odborníka Martinovi potvrdil, že s najväčšou pravdepodobnostou sa o psychospirituálnu krízu naozaj jednalo. Namiesto strachu z duševnej choroby mohli byt neobvyklé skúsenosti uchopené z pohladu, na základe ktorého sú považované za súčasṫ ozdravného procesu.

Takéto spôsoby premýšllania o neobvyklých symptómoch vychádzajú do vel'kej miery z diela Christiny a Stanislava Grofových, ktorí tvrdia, že pokial' sú niektoré neobvyklé stavy správne pochopené a ich priebeh a vývoj je podporovaný (namiesto potlačenia bežnými psychiatrickými postup- 
mi), môžu byt liečivé a velmi priaznivo pôsobit na jedinca, ktorý ich preživa. ${ }^{66}$ I velmi neobvyklá skúsenost̉ mohla byt teda za určitých podmienok zvládnutá bez väčšieho škodlivého dopadu na d’alší Martinov život. Ten ju dokonca vníma ako obohatenie:

Psychospirituální krize pro mě vlastně byla obrovskej dar, přestože to ze začátku vypadalo divoce. ... Já už jsem to měl nějaký takový jako vybudovaný ten svět. Po těch patnácti, nebo devíti letech intenzivních meditací a šesti letech nějakýho jako zakořeňování, to najednou přišlo a ten duchovní svět, který už byl takovej jasnej a rozuměl jsem tomu, tak se sesypal jak domeček z karet. A musel jsem začít budovat znova. $^{67}$

Vyššie uvedené príklady brazílskej liečitel'ky a môjho komunikačného partnera Martina ukazujú, že zapojenie nepatologizujúceho výkladového rámca môže zohrat významnú úlohu v spôsoboch, ktorými bude daná situácia zvládaná. Nevšedný duševný zážitok, pohybujúci sa v tomto prípade na pomedzí psychózy a náboženskej skúsenosti, je možné pochopit a spracovat rôznymi spôsobmi. Leudar s Thomasom píšu, že rozličné sociálne postavenie skúseností podmieňuje, čo môže človek s nimi robit, a to i za predpokladu, že by si boli v iných aspektoch podobné. ${ }^{68}$ Predpokladám, že závery týchto autorov, venujúcich sa najmä skúsenostiam počutia hlasov, sú uplatnitelné i na dalšie formy neobvyklých symptómov. Podla Leudara s Thomasom hrajú reakcie okolia na ludí počujúcich hlasy, reakcie kamarátov, rodín, ako i širšej spoločnosti, centrálnu úlohu v tom, ako bude daný človek rozumiet svojej skúsenosti, ako sa s ňou bude vyrovnávat. Odpoved' okolitých ludí, či už si neobvyklú skúsenost̉ vážia, alebo z nej majú strach, má vel'ký význam. ${ }^{69}$ Neobvyklé symptómy tak môžu byt' začlenené do rozličných sietí tvorených lekárskymi a náboženskými inštitúciami, vztahmi s rodinou a priatelmi, ako i rozličnými výkladovými schémami a s nimi spojenými praktikami. Z pomyselnej križovatky hraničného zážitku sa dá v niektorých prípadoch vykročit viacerými cestami.

Brazílskej žene trpiacej z pohladu západnej psychiatrie disociatívnou poruchou osobnosti umožnila žit dôstojný a spokojný život náboženská komunita umbandy, na čele ktorej tradične stojí šaman. Jej skúsenosti z posadnutia duchmi si komunita s úctou cenila ako skutočné a verejnosti prospešné zjavenia.

Martina, človeka s dlhodobou meditačnou praxou, otvoreného duchovným témam, upokojila odpoved' terapeuta, ktorý je za splnenia určitých diferenciálne-diagnostických podmienok ochotný neobvyklé symptómy

66 Ch. Grofová - S. Grof, Krize duchovního vývoje..., 8.

67 Rozhovor z dňa 8. 1. 2019.

68 I. Leudar - P. Thomas, Voices of Reason..., 49.

69 Ibid., 125-126. 
a prácu s nimi interpretovat ako súčast̉ cesty k vyšším formám psychického zdravia. Takéto ubezpečenie Martinovi pomohlo zbavit sa strachu z možných budúcich scenárov. Spomienka na nezvyčajné symptómy prestala byt spájaná s niečím negatívnym, chorobným a žitie ohrozujúcim a bola včlenená do zmysluplnejšieho a nádejnejšieho výkladového rámca. Skúsenoste z púte sa tak nestala prejavom choroby, ktorý by sa mohol velmi pravdepodobne opätovne vrátit. Martin bol uistený o tom, že je na dobrej ceste. Nezvyčajné symptómy interpretované ako prejavy Ducha vzbudzujú strach menej než nezvyčajné symptómy interpretované ako prejav patológie:

Todle byla ta zásadní pomoc, kterou jsem dostal. Za tu jsem neskonale vděčnej. Protože tím jako mě ujistil, že je všechno v pořádku. Že to prostě je jenom nějaká forma projevu Ducha. Oukej, to není nic, čeho bych se měl bát. ${ }^{70}$

\section{Nezvyčajné symptómy ako autobiografická disrupcia}

Ludia, s ktorými som uskutočnil rozhovory, prežívali nevšedné a neobvyklé mentálne a fyzické stavy. Nekontrolovatelne sa im triaslo telo, pred vnútorným zrakom sa im zjavovali búrlivé predstavenia farieb, obrazcov a groteskných tvarov a tvárí. Komunikovali s bytostami, ktoré by mali existovat len v náboženských a mytologických textoch či preživali prekročenie obvyklých hraníc telesnej skúsenosti. Niekedy v nich tieto situácie vyvolávajú strach a zmätok, niekedy im prinášajú mier a krásne pocity. Nech už však zažívajú stavy príjemné či nepríjemné, väčšinou spočiatku nedisponujú znalostami, prostredníctvom ktorých by si svoje nové skúsenosti vedeli vysvetlit, či ich kontrolovat. Pocity neistoty a váhania sú tak pričastou súčastou situácie, v ktorej sa vyskytli. Komunikačná partnerka, ktorej budem hovorit Lenka, začala mat strach z opustenia tela. Akoby sa vzd’al'ovala niekam preč, akoby sa všetko strácalo. Bála sa. Tento zážitok zvykol byt sprevádzaný i zažívacími tažkostami a celkovou fyzickou slabostou. Svoju situáciu si nevedela vysvetlit. Navštívila všeobecnú lekárku a tá jej spravila sadu rozličných vyšetrení. Z ich pohladu bolo všetko v poriadku. Lenka sa ale v poriadku necítila. Problémy nad’alej pretrvávali, no vedomost' o tom, $\mathrm{z}$ čoho pramenia a ako sa ich zbavit, $\mathrm{k}$ dispozícii nebola:

Ale to mi až tak dalo takú neistotu, povie mi, že mi nič nie je, ale mne niečo je a čo to je proste? To bol ešte väčší strach z toho, že nevieš, že čo sa ti deje. Vieš, že to je podla mňa to najhoršie. To je podla mňa ten najväčší faktor, ktorý ti potom proste prevláda $v$ tom živote, že ty nevieš, čo ti je, takže nevieš, čo s tým máš spravit.. ${ }^{71}$

70 Rozhovor z dňa 8. 1. 2019.

71 Rozhovor z dňa 11. 3. 2019. 
Vel'kým problémom pre mojich komunikačných partnerov neboli len pocity neistoty a nevedenia, ale i obmedzenia a zmeny v praktickom chode života, prameniace $\mathrm{z}$ objavujúcich sa symptómov. Jana absolvovala určitú modernú európsku obdobu indiánskeho prechodového rituálu, ktorý bol po fyzickej i duševnej stránke pomerne náročný. Jej pôvodnou motiváciou $\mathrm{k}$ účasti na tejto udalosti bolo životné pozastavenie sa po úspešnom absolvovaní vysokej školy a príprava na čo najkvalitnejšie vykonávanie budúcej, vopred jasne vyhliadnutej práce. Rituál však mal na Janu nezamýšlaný účinok. Namiesto vízie, ktorej obsahom by boli informácie o tom, ako čo najlepšie uskutočnit naplánované predstavy, prišla niekol'komesačná neschopnost' nájst' v akejkolvek činnosti zmysel. Vôbec ráno vstat̉ z postele sa pre Janu stalo náročným počinom. K pocitom márnosti sa pridala i zmena $\mathrm{v}$ zmyslovom vnímaní. Zvuky a tvary zrazu pôsobili neprirodzene. V́rzganie či buchnutie dverí znelo akosi inak. Kachličky v kúpelni sa začali vlnit. Pre Janu bolo náročné túto zmenu prijat. Pokračovanie $\mathrm{v}$ bežných zabehnutých spôsoboch života sa v týchto nových podmienkach stalo náročným. Občas musela zavolat do práce, že nepríde.

Skúsenosti podobné Lenkiným a Janiným môžeme z pohladu sociológie zdravia a choroby chápat ako určitý druh biografického narušenia (biographical disruption). Podla Buryho sú choroby, špeciálne tie chronické, typom skúseností, pri ktorých sa narúšajú štruktúry každodenného žitia a s nimi spojené formy vedomostí. Stav biografického narušenia možno podla Buryho analyticky rozdelit na tri navzájom súvisiace štádiá. V prvom z nich dochádza $\mathrm{k}$ narušeniu zaužívaných predpokladov a správania, k prelomeniu bežných hraníc prežívaného sveta. Následne dochádza k zásadnejšiemu zlomu $\mathrm{v}$ našich spôsoboch vysvetlovania sveta a $\mathrm{k}$ fundamentálnemu prehodnoteniu osobnej biografie a predstáv, ktoré o sebe máme. Posledné štádium, ked' sme už boli nútení prehodnotit naše zabehnuté koncepcie o svete a našom mieste $\mathrm{v}$ ňom, ako i prehodnotit naše stratégie vedenia života, spočíva v odpovedi na vzniknutý zlom. Teda v mobilizácii rôznorodých zdrojov, prostredníctvom ktorých sa náročnej situácii môžme postavit. $^{72}$

V prípade mojich komunikačných partnerov sa momentom prepuknutia biografickej disrupcie stáva vyvstanie neobvyklých psychických a fyzických symptómov. Poprípade ich dlhodobejšie pretrvávanie či ich zvyšujúca sa intenzita, prekračujúca mieru únosnosti vzhladom na normálne fungovanie v každodennom živote. Následné hladanie pomoci môže pozostávat len z rozhovoru s priatelom či rodinou. Napokon pravdepodobne príde na rad návšteva psychiatrickej kliniky. V iných prípadoch možno skôr vyhladanie alternatívnejšej psychoterapeutickej pomoci či alternatívneho liečitela.

72 M. Bury, ,,Chronic Illness as Biographical Disruption...“, 169. 
Ondrej začal trpiet intenzívnymi stavmi úzkosti. V hlave sa mu točili farebné víry. Smiali sa na neho klauni. Vystrašený a zmätený vyhladal psychiatra. Predpísané lieky však nedokázal strávit. Autogénny tréning odporučený psychologičkou nefungoval. Zúfalstvo prameniace $\mathrm{z}$ neúspešných pokusov nájst' pomoc, i napriek počiatočnému odporu voči čomukolvek zaváňajúcemu alternatívnostou, napokon Ondreja priviedlo k organizácii Diabasis. O tej sa dopočul od dobrého priatela, ktorému sa mohol so svojou starostou zdôverit.

Chápat praktiky a koncepty alternatívnej spirituality ako súčasṫ zdrojov mobilizovatelných za účelom zvládnutia krízy mi prináša lepšie pochopenie ich pozície ako praktického nástroja pre zvládanie zlomovej situácie. Vyššie spomínaná komunikačná partnerka Lenka mala strach ostat osamote. Stratila dôveru v správne fungovanie svojho tela. Bála sa, že stratí vedomie a nablízku nebude nikto, kto by jej pomohol. Strachuplné myslenie na tento scenár zhoršovalo jej úzkost́, ako i pocit „strácania sa preč z tela“. Nenachádzala východisko. Všeobecný lekár pomôct nevedel. Pri vyšetreniach ani pri vykonaní krvných testov neodhalil žiadny problém. Postupne našla vlastné spôsoby, ako si organizovat život smerom k prijatelnej únosnosti. Nebola to však, podla jej slov, žiadna výhra. Vyhladávala kontakt s lud'mi a rozprávala sa s nimi o bežných veciach, aby tým odvrátila pozornost' od svojho strachu zo zmeny vedomia. Prítomnost blízkych ludí ju upokojovala. Vyhladávala situácie, v ktorých sa cítila bezpečne a bála sa situácií, ktoré mohli pre ňu byt náročné, napríklad cesta vlakom. Určitý pocit istoty jej poskytovala skúsenosṫ toho, že napriek obavám a prežívaniu nepríjemných pocitov „strácania sa vedomia preč z tela“ nikdy naozaj neodpadla. Väčším problémom bol samotný strach z tejto možnosti. V tomto aspekte prežívania jej napokon pomohla návšteva jedného z psychoterapeutov pracujúcich s konceptom psychospirituálnej krízy. Ked’ mu opisovala prvú skúsenost’ „strácania sa preč z tela“, s živým záujmom ju počúval. Povedal, že to s najväčšou pravdepodobnostou vyzerá na psychospirituálnu krízu. Vysvetlil Lenke, že sa danej skúsenosti nemusí obávat. Ak by aj naozaj odpadla, k čomu však nikdy nedošlo, tak ju to nijak neohrozí:

Povedal mi, že ked' to budem cítit, že sa to ako keby deje, tak proste lahnút, a ako keby si išiel vedome do toho, že odpadneš. Snažila som sa tomu proste venovat pozornost'. Nie, že to vyvolávat', ale proste, už ked' sa to stane, tak vediet', ako na to. Ako na to zareagovat a proste to nezvyšovat zbytočne. Alebo ako keby vedome ideš do toho, že zaspíšs. L'ahnút, upokojit sa, ked' tak radšej zavriet' oči a spat, a že proste aj kebyže odpadneš, tak proste spíš. Samozrejme nikdy neprišlo k tomu odpadnutiu. Takže som to vedela asi takto nejako. ${ }^{73}$

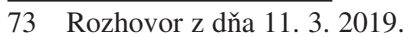


Človek s autoritou psychoterapeuta rozpoznal Lenkin opakujúci sa zážitok ako prejav psychospirituálnej krízy. Tým ho začlenil do kontextu nových významov a spojil ho s odlišnými predstavami o jeho možných dopadoch na Lenkin život. Strach z telesného zrútenia sa, predstava zvyšujúca úzkosṫ z neobvyklej skúsenosti, bol zmiernený novým výkladovým rámcom. Neznáma skúsenost sa jej po rozpoznaní odborníkom stala o niečo známejšou a menej nebezpečnou. Psychoterapeut Lenkin strach dokonca zlahčil príbehom o tom, že si s kamarátmi podobné zážitky ako mladíci pre pobavenie privolávali dobrovolne, prostredníctvom manipulácie so svojím dychom. Lenka nadobudla praktické spôsoby, prostredníctvom ktorých môže reagovat na neobvyklé symptómy, ked’ sa znovu objavia. Získala nástroj, ktorý jej vrátil nad neobvyklou skúsenostou kontrolu. Zbavila sa tak bezradnosti a bezmocnosti.

\section{Hraničné situácie}

Neobvyklé symptómy mojich komunikačných partnerov sú často nejasnej povahy a je možné s nimi na základe odlišných pochopení a začlenení do rozličných praktických usporiadaní pracovat rôznymi spôsobmi. So škálou neobvyklých symptómov typických pre mojich komunikačných partnerov pracuje v našej spoločnosti najmä klasická biomedicínsky orientovaná psychiatria. Okrem nej napríklad ale i rôzne alternatívne psychoterapie, vychádzajúce zo základov transpersonálnej psychológie, medzi ktoré patrí i v tomto texte často spomínaná Diabasis. Mnoho mojich komunikačných partnerov má skúsenosṫ s klasickou psychiatriou, ako i s transpersonálne založenou psychoterapiou. Psychoterapeuti a psychológovia z Diabasis do určitej miery s inštitúciou klasickej psychiatrie spolupracujú. Občas sú k niektorým novým psychiatrickým pacientom privolaní prekonzultovat možnost' chápat dotyčného človeka ako niekoho, kto sa nachádza v psychospirituálnej kríze. O psychospirituálnej kríze prednášajú študentom psychiatrie a adiktológie na Karlovej univerzite v rámci predmetu Transpersonálna psychológia. Študenti psychiatrie a adiktológie prístupy založené na transpersonálnej psychológii chápu a niektorí s nimi sympatizujú. ${ }^{74}$ Svety biomedicínskej psychiatrie a transpersonálnej psychológie majú teda mnoho styčných plôch, i ked' sa ich pohlady na problematiku duševného zdravia v určitých aspektoch líšia.

Špecifickou črtou mojich komunikačných partnerov je zdráhanie sa chápat svoje neobvyklé symptómy výlučne z pohladu biomedicínskej psychiatrie. Z rozličných dôvodov hladajú odlišné kultúrne zdroje pre

74 Tieto informácie som načerpal z kurzu o transpersonálnej psychológii, ktorý som na Karlovej univerzite navštevoval v roku 2018. 
vytvorenie pohladu na svoje skúsenosti. Alžbeta má oficiálne diagnostikovanú jednu z foriem schizofrénie. Lieky užíva len výnimočne - ked' skončí hospitalizovaná v psychiatrickej liečebni; vtedy jej pomáhajú spomalit príliš divoko asociujúce myslenie a prispôsobit vnímanie bežnejšiemu rozpoloženiu. Sama o sebe však ako o schizofreničke nepremýšla. O svoje nevšedné zážitky sa teoreticky vel'mi zaujíma, pátra po ich možných nepatologizujúcich interpretáciách, číta knihy, navštívila transpersonálne založeného psychoterapeuta. Neobvyklé skúsenosti považuje skôr za životné obohatenie a súčasṫ duchovnej cesty. Dávajú jej niečo, k čomu ostatní ludia nemajú prístup. Chápat ich ako dysfunkciu čakajúcu na odstránenie je pre ňu neprijatel'né. ${ }^{75}$

Duševnú chorobu a psychospirituálnu krízu nepovažujem za samy o sebe existujúce fenomény, za reálne existujúce odlišné ontologické sféry. Po vzore Konopáskovho textu „V čom spočíva pravda náboženskej skutočnosti?"“ sa skôr snažím chápat existujúce podstaty vecí nie ako východisko, ale ako problém, ktorý je potrebné vysvetlit. ${ }^{76}$ Konopásek píše, že takéto nejednoznačné zážitky majú zvláštny význam pre súčasné diskusie o spiritualite, religiozite a kultúrnej odlišnosti v medicíne všeobecne a v psychiatrii obzvlášti ${ }^{77}$ Zaoberajúc sa problematikou údajných zjavení/posadnutostí tvrdí, že na takéto situácie môžeme nahliadat skrze kategórie duševných chorôb, ale i skrze kategóriu duchovného utrpenia. Takýto prístup je nevšedný, pretože na problematiku zjavení v súvislosti s dvojicou vyššie spomenutých kategórií sa nepozerá vo výlučných termínoch „,bud'-alebo“. Namiesto toho vníma údajné zjavenia/posadnutosti ako tzv. hraničný objekt. Ako „hraničné objekty“ sa označujú súcna, ktoré sú síce pomerne pevné a určité, avšak zvláštnym, nevýlučným spôsobom náležia viacerým rozličným svetom súčasne. Sú dostatočne tvárne na to, aby sa prispôsobovali miestnym potrebám a tlakom, avšak zároveň natol'ko robustné, aby si v rôznych situáciách udržali svoju identitu. ${ }^{78}$ Podla Konopáska nejde len o zložité pomenovávanie toho, že jedna a tá istá vec je z rozličných pohladov nahliadaná rôzne. Ide o viac než len o osobnú interpretáciu. Ide o celé súbory kolektívnych praktík a materiálnych usporiadaní, prostredníctvom ktorých môže mat jedna a tá istá vec viacnásobnú existenciu - ako keby objektívne išlo o niekol'ko rozličných vecí. ${ }^{79}$ Takýto symetrický prístup však nie je samozrejmostou. Jeho zmyslom je rozptýlit dojem nevyhnut-

75 Zápisky z výskumného denníka 22. 8. 2019.

76 Z. Konopásek, „V čem spočívá pravda náboženské skutečnosti?...“, 92.

77 Ibid., 95.

78 Ibid., 95-96.

79 Ibid., 96. 
nosti určitého pohladu. ${ }^{80}$ Takúto symetriu dosahujeme tak, že sa snažíme všetky zúčastnené stanoviská a výpovede merat rovnakým metrom. Ontologický status súcien, ktoré vyznáva jedna či druhá strana, dávame skrátka pred zátvorku a pravdu i omyl, racionalitu i iracionalitu, vedu i náboženstvo popisujeme a vysvetlujeme súmeratelnými prostriedkami. ${ }^{81}$ Skôr než o úplnú nestrannost však ide o opatrné heuristické stránenie „slabšej“ strane. Jej pohlad tak nemôžme polahky zhodit zo stola ${ }^{82}$ a zbavíme sa pokušenia vidiet ho ako nerozumný. Ide o obnovu uznania racionality tam, kde bola silnejšou stranou zamietnutá či zabudnutá. ${ }^{83}$ Takýto postoj je špecifickou reakciou na niečo, teda nie je vopred daným postojom. Dostáva zmysel až vtedy, ked' začne naozaj o niečo íst'. ${ }^{84}$

Alžbete naozaj o niečo ide. Hospitalizovaná v psychiatrickej liečebni nemala možnostê o svojich symptómoch rozprávat a hladat ich možný význam či o nich diskutovat iným než psychiatrickým jazykom. Jej neobvyklé symptómy boli vnímané v prvom rade ako bludy, ktoré je potrebné potlačit'. Je možné, že v danej chvíli bolo naozaj najdôležitejšie dané symptómy potlačit. Nikto sa s ňou však o nich nechcel rozprávat ani nasledujúce týždne, ked’ už boli farmakologickou liečbou potlačené. Ako religionista nemôžem vediet, čo je z lekárskeho hladiska správny postup. Od svojej komunikačnej partnerky však viem, že o svojich neobvyklých symptómoch a o ich možnej povahe a príčine sa s odborníkmi rozprávat chcela. Aby mohla získat na svoje skúsenosti odlišný pohlad, musela pátrat sama v knihách či si musela na rozhovor vyhladat alternatívneho psychoterapeuta. Aké problémy Alžbete pomáha riešit, ked' o svojich symptómoch premýšla a rozpráva ako o prejavoch psychospirituálnej krízy či ako o duchovných zážitkoch? Aké rôzne polia praktických manipulácií sa pred Alžbetou otvárajú, ked’ je na jej symptómy nahliadané ako na patológiu alebo ako na prejav psychospirituálnej krízy? Aké aspekty jej života sú týmito rozličnými výkladmi a praktikami ovplyvňované a aké problémy či riešenia jej poskytujú? Na tieto otázky budem svojím d’alším výskumom hladat podrobnejšie odpovede.

Psychické a fyzické symptómy mojich komunikačných partnerov ponímam ako hraničné objekty. Rešpektovanie ich nejednoznačnej povahy mi umožňuje vnímat úlohu rôznych praktík a konceptov alternatívnej spirituality pri zvládaní životnej krízy vo vztahoch s d’alšími mobilizovanými stratégiami a praktikami, ktoré ako spirituálne nazývat nezvykneme.

80 Sergio Sismondo, An Introduction to Science and Technology Studies: Second Edition, Chichester: Wiley-Blackwell 2010, 121.

81 Z. Konopásek, „V čem spočívá pravda náboženské skutečnosti?...“, 92.

82 Ibid.

83 S. Sismondo, An Introduction to Science and Technology Studies..., 121.

84 Z. Konopásek, „V čem spočívá pravda náboženské skutečnosti?...“, 95. 
Môžem tak lepšie pochopit odlišné pozície rôznych prístupov tvoriacich využitel’né zdroje pre zvládnutie skúmanej krízy, ako i praktické možnosti, ktoré otvárajú.

\section{Záver}

V tomto článku som sa pokúsil predostriet jeden z možných prístupov k skúmaniu rozličných praktík a konceptov alternatívnej spirituality v ich prepojenosti s riešením rozličných náročných ludských situácií. Mojím úmyslom bolo aspoň skromne podporit tendenciu skúmat spiritualitu v prostredí žitej každodennosti a ukázat jeden z kontextov, v ktorých by sme tieto praktiky a koncepty mohli skúmat vo väčšej spojitosti s d’alšími oblastami každodenného zvládania života. Konkrétne som sa zameriaval na praktické funkcie a významy, ktoré môžu mat pri procese vyrovnávania sa s náročnými životnými situáciami spôsobenými nečakaným objavením sa neobvyklých psychických a fyzických symptómov.

Uviedol som takisto príklady z textov iných než religionistických, ktoré by mohli slúžit ako inšpirácia pre naše úvahy o praktických významoch a funkciách alternatívnej spirituality. Tieto texty pochádzali $\mathrm{z}$ vedných oborov, ktoré sa s tematikou spirituality stretávajú v kontexte riešenia vážnych problémov ludských životov, akými sú napríklad zdravotné problémy či nezvyčajné zážitky vybočujúce z normy bežného prežívania. Išlo o texty prameniace $\mathrm{z}$ výskumov transkultúrne orientovanej psychiatrie a texty etnologicky zameranej kultúrnej antropológie medicíny. Oba tieto prístupy sú špecifické zohladňovaním vztahov medzi konkrétnou historickou dobou, kultúrou daných spoločností a formami chápania ludského utrpenia. Ďalšou nemenej dôležitou charakteristikou týchto prístupov je záujem o utrpenie konkrétnych ludí, v snahe pochopit škálu praktických problémov, s ktorými sa stretávajú.

Komunikační partneri, s ktorými som uskutočňoval rozhovory, sú určitým spôsobom špecifickí. Ide o ludí, ktorí v nejakej fáze svojich životov prežívali neobvyklé psychické a fyzické symptómy prístupné odlišným výkladom. Na ich príkladoch si namiesto abstraktných odpovedí z dotazníkov môžeme spravit konkrétnejšiu predstavu o tom, čo prakticky môže $\mathrm{v}$ rozličných kontextoch znamenat, ak niekto povie, že sa napríklad cíti „viac spirituálne“ alebo „viac naplnene“. Videli sme napríklad, že Martinovi pomohlo uistenie o tom, že neobvyklé skúsenosti z púte môže chápat nie ako poruchu mozgu, ale ako prejav Ducha. Po dôkladnom preskúmaní povahy jeho symptómov bol psychoterapeutom ubezpečený o liečivom potenciáli jeho zážitku. Neobvyklé symptómy boli začlenené do inej sústavy významov a predstáv a Martin nemusel žit v strachu z toho, že by bol duševne chorý. 
Môj príspevok nie je kritikou ani spochybnením výkladov a postupov klasickej biomedicínskej psychiatrie. Mojím zámerom nie je tvrdit, že l’udia s neobvyklými symptómami nepotrebujú brat lieky či navštevovat klasických psychiatrických odborníkov. Namiesto toho ukazujem, že výskyt neobvyklých symptómov nemusí byṫ vždy interpretovaný ako patológia a že niektorí ludia sa snažia vyhnút situácii, v ktorej by mohli byt ich skúsenosti za patológiu označené. So svojimi neobvyklými symptómami sa tak snažia pracovat’ spôsobmi, pri ktorých sa ich skúsenost nepovažuje za prejav choroby, no skôr za duchovnú krízu. Touto cestou som chcel na konkrétnych príkladoch ukázat na praktické funkcie, ktoré môžu rozličné praktiky a koncepty alternatívnej spirituality zohrávat pri riešení konkrétnych životných problémov. 


\section{SUMMARY}

\section{The Practical Meaning of Spirituality in the Process of Coping with Unusual Mental Symptoms}

This article is primarily theoretical. The main purpose is to outline a research approach that would contribute to a social-scientific view of alternative spirituality in the context of everyday life. I will explore the possible meanings and functions that alternative spirituality can have as one of the cultural resources that is used to cope with unusual physical and mental symptoms. Typical examples of such symptoms are hearing voices, communication with non-human beings, strange feelings in the body, uncontrollable body movement, and changes in sensory perception. These symptoms can result in a variety of personal and professional crises.

I try to illustrate the proposed theoretical approach to the study of spirituality using empirical data from my dissertation research, which were obtained through biographical interviews. The basic criterion for the selection of communication partners and their inclusion in the research was their experience with unusual mental and physical symptoms and their effort to manage this experience through the concept of psychospiritual crisis. I try to show how alternative spirituality in the context of the concept of psychospiritual crisis helped my communication partners to cope with their symptoms through a new understanding of this experience. To do this, I employ methodological and theoretical tools from various scientific fields, such as the anthropology of health and illness, transcultural psychiatry, and science and technology studies.

Keywords: alternative spirituality; coping strategy; healthcare; psychospiritual crisis; mental illness; boundary objects.

Department for the Study of Religions

MATEJ PAULÍK

Faculty of Arts

Masaryk University

Arna Nováka 1

60200 Brno

Czech Republic

matej.paulik44@gmail.com 